Article

\title{
A Bird's Eye View: Supranational EU Actors on Twitter
}

\author{
Sina Özdemir ${ }^{1, *}$ and Christian Rauh ${ }^{2}$ \\ ${ }^{1}$ Department of Sociology and Political Science, Norwegian University of Science and Technology, Norway \\ 2 Research Unit Global Governance, WZB Berlin Social Science Center, Germany \\ * Corresponding author (sina.ozdemir@ntnu.no)
}

Submitted: 12 July 2021 | Accepted: 6 October 2021 | Published: 17 February 2022

\begin{abstract}
Given the politicization of European integration, effective public communication by the European Union (EU) has gained importance. Especially for rather detached supranational executives, social media platforms offer unique opportunities to communicate to and engage with European citizens. Yet, do supranational actors exploit this potential? This article provides a bird's eye view by quantitatively describing almost one million tweets from 113 supranational EU accounts in the 2009-2021 period, focusing especially on the comprehensibility and publicity of supranational messages. We benchmark these characteristics against large samples of tweets from national executives, other regional organizations, and random Twitter users. We show that the volume of supranational Twitter has been increasing, that it relies strongly on the multimedia features of the platform, and outperforms communication from and engagement with other political executives on many dimensions. However, we also find a highly technocratic language in supranational messages, skewed user engagement metrics, and high levels of variation across institutional and individual actors and their messages. We discuss these findings in light of the legitimacy and public accountability challenges that supranational EU actors face and derive recommendations for future research on supranational social media messages.
\end{abstract}

\section{Keywords}

European Union; political communication; politicization; social media; text analysis

\section{Issue}

This article is part of the issue "Analyzing Citizen Engagement With European Politics Through Social Media" edited by Pieter de Wilde (Norwegian University of Science and Technology), Astrid Rasch (Norwegian University of Science and Technology), and Michael Bossetta (Lund University).

(C) 2022 by the author(s); licensee Cogitatio (Lisbon, Portugal). This article is licensed under a Creative Commons Attribution 4.0 International License (CC BY).

\section{Introduction: Why We Should Care About Supranational Twitter Activity}

The European Union (EU) has an increasingly precarious relationship with its citizens. Incidences such as the failure of constitutional referenda in 2005, the raging debates about supranational authority during the Euro and Schengen crises after 2009 and 2015, the Brexit decision of 2016, and more generally, the success of Euroscepticism in national and European election campaigns exemplify the growing politicization of European integration in which a permissive consensus among the wider citizenry cannot be taken for granted (de Wilde \& Zürn, 2012; Hooghe \& Marks, 2009; Rauh, 2021a).
In these controversial public debates, especially the EU's supranational institutions are frequent addressees, often serving as a scapegoat for unpopular policies (Gerhards et al., 2009; Harteveld et al., 2018; Heinkelmann-Wild \& Zangl, 2020; Rittberger et al., 2017; Schlipphak \& Treib, 2017; Traber et al., 2020). Supranational institutions can try to influence these debates as well, and they seem to start approaching their public communication strategically (Ecker-Ehrhardt, 2018, 2020; Rauh, 2021c; Rauh et al., 2020). Yet and still, the extant literature attests various communication deficits rooted in either the internal setup of supranational institutions or in external obstacles they face in traditional media (e.g., Altides, 2009; Boomgaarden et al., 2013; Brüggemann, 2010). 
Much hope is ascribed to social media in this setting. Theoretical analyses and case studies suggest that their transnational outreach, low costs of messaging, and an emphasis on user engagement render social media particularly attractive for the otherwise rather detached supranational institutions (e.g., Barisione \& Michailidou, 2017; Krzyżanowski, 2020; Zaiotti, 2020). However, extant large-n social media studies focus only on EU actors with direct electoral accountability, such as the Council and European Parliament (EP) representatives (European Parliament Directorate General for Parliamentary Research Services, 2021; Fazekas et al., 2021; Haßler et al., 2021; Nulty et al., 2016; Umit, 2017), thereby neglecting exactly those executive institutions that citizens most strongly associate with the EU as a polity (Silva et al., 2021).

Thus, this article provides an encompassing mapping of how supranational institutions and actors use Twitter, a key social media platform. Our quantitative description of more than 960,000 supranational tweets from 113 accounts in the 2009-2021 period is guided by two questions. First, we ask to what extent supranational messages are geared to be comprehensible by the wider citizenry. We thus aggregate linguistic and media features of supranational tweets. Second, we ask to what extent supranational engagement generates publicity. Here, we quantify direct on-platform user engagement and relate it to the features of supranational messages.

Benchmarking these indicators to large samples of messages from random users, national executive institutions, and other regional organizations shows that supranational executives of the EU increasingly embrace social media. Message output has grown markedly and, while the text of supranational messages is still comparatively hard to access for the average citizen, supranational actors champion non-textual communication, enriching their messages with visual content, external links, and meta-linguistic elements such as emojis much more often than other executives do. In terms of publicity, the number of followers has been strongly increasing at least for some supranational EU actors. But direct user engagement rates remain low in absolute terms and are more or less comparable to those of national executives. On many dimensions, we furthermore find notable differences between institutional and personal EU accounts, suggesting that more personalized communication is associated with more citizen engagement. Against the backdrop of public EU politicization and traditional communication deficits, our bird's eye view on supranational Twitter thus offers fruitful guidance for further research on executive public EU communication on social media.

\section{Effective Supranational Communication and the Potential of Social Media}

Communication is vital for the legitimacy of political systems. Addressees of political authority usually demand some form of justification. Authority holders thus engage in nurturing the belief in their claim to rule among relevant audiences (Tallberg \& Zürn, 2019; Weber, 2013, p. 450). For supranational EU institutions, this has become a more challenging task. Beyond their traditional audiences-delegating principals in the Council, sometimes in the $E P$, or specific stakeholders in the respective policy area-growing public EU politicization renders the wider European citizenry a relevant audience as well (Rauh, 2021a).

Reaching this audience is especially important for the otherwise rather detached supranational institutions. For political authorities without direct accountability mechanisms such as elections, specific and diffuse support become blurred quite quickly. Where the general public has no direct routes to hold decision makers to account, specific unfavorable policy choices or misconduct of office holders can easily damage the popular legitimacy of the political system as a whole. In a politicized context, disagreement with policy choices may quickly turn into more fundamental "polity contestation" (de Wilde \& Trenz, 2012).

It is thus unsurprising that communication efforts of institutions beyond the nation state respond to politicization shocks (Bressanelli et al., 2020; Ecker-Ehrhardt, 2018; Rauh et al., 2020; Schimmelfennig, 2020). We do not know, however, to what extent the resulting messages are suited to reach the wider citizenry in the first place. In this article, we are interested in two message characteristics that we consider necessary conditions for effective public self-legitimation of any specific type or content.

The first condition is comprehensibility. In order to reach the average citizen, as opposed to the specialized and highly knowledgeable traditional audiences, supranational messages should not be overly demanding in terms of the cognitive mobilization required to decipher their political content. Citizens integrate information into their political knowledge structure much better if it is delivered in an easy-to-comprehend manner (Bischof \& Senninger, 2018; Tolochko et al., 2019). To have any effect on citizens' legitmacy beliefs about supranational institutions, the messages have to be comprehensible in the first place. Moreover, citizens explicitly want the EU to be more transparent (Schafer et al., 2021).

The second condition is publicity. Publicity refers to the degree to which the broader audience, as opposed to atomized individuals, engages with the issues, acts, and processes of the political system (Hüller, 2007). Comprehending the information is not enough if citizens do not engage with it, digest it, and actively link it to debates they care about. Only with a sufficient degree of publicity can supranational communication be expected to influence both individuals' perception of supranational institutions and the broader public debate about the European polity.

Supranational institutions, however, face serious obstacles for comprehensible messaging with high 
degrees of publicity. Parts of these obstacles are internal. We know that supranational communication is often subject to internal conflicts and competition over limited resources (Altides, 2009; Bijsmans \& Altides, 2007; Hartlapp et al., 2014, Chapter 9). In institutions with delegated powers that involve high levels of expertise, consensus orientation, and diplomatic restraint, public outreach has traditionally also been a secondary concern (Brüggemann, 2010; Meyer, 1999). Moreover, supranational institutions may try to evade controversial debates by avoiding clear communication (Biegoń, 2013; Bressanelli et al., 2020; de Wilde \& Zürn, 2012; Schimmelfennig, 2020). Traditional communication efforts such as press releases or public speeches of supranational actors are thus often hardly comprehensible for the average citizen (Rauh, 2021b; Rauh et al., 2020).

Against these internal constraints on comprehensible messaging, social media offer attractive features to supranational institutions. First, costs are comparatively low: It takes mere minutes to set up an account and they are easy to maintain. Second, social media platforms usually incentivize clear and concise messages that are also cheaper to produce and to distribute than, for instance, press releases. Third, social media offer various multimedia features that aid message comprehension beyond textual content (Tang \& Hew, 2018).

Other obstacles are external. Supranational institutions focus on the European interest, but mass-mediated public spheres tend to be fractured along national borders, languages, and media systems (Koopmans \& Statham, 2010; Risse, 2014; Trenz, 2004; Walter, 2017). National media are rather selective in covering EU affairs, as traditional journalistic selection logics are often partial to national interests, domestic executives, and their challengers (De Vreese, 2001; De Vreese et al., 2006; Trenz, 2008). Media coverage of the EU is then primarily driven by controversial and contested events such as summits of the heads of state and government, EP elections, and scandals on the European level (Boomgaarden et al., 2013; Hobolt \& Tilley, 2014). Thus, supranational institutions have a hard time to achieve positive publicity via traditional media channels.

Social media platforms hold promise here as well. They provide users with a low-hurdle continuous information source that does not require conscious information search. Moreover, social media allow citizens to engage with content beyond fractured national boundaries (Bossetta et al., 2017). Users may encounter supranational messages in their timelines, through their connections, or they could simply follow the respective accounts by a simple click. Furthermore, social media imbue users with a degree of gatekeeping power (Wallace, 2018). The decentralized structure allows choosing which messages to amplify. This gives supranational EU actors as well as citizens some freedom to circumvent traditional media selection logics in generating publicity. Moreover, social media, specifically Twitter, can act as a "double-barrelled gun": recent research shows that journalists tend to pick up tweets from political actors when they have gone viral and incorporate them in traditional news (Cage et al., 2020; Oschatz et al., 2021).

To be sure, social media hardly offer a panacea to the EU's communication deficits, but they do promise an additional communication channel with attractive features to overcome obstacles for comprehensible supranational messaging to the average citizen with higher levels of publicity. However, do supranational executives actually exploit this potential?

\section{Data: Supranational Tweets and Benchmarks}

Our analyses focus on Twitter for three reasons. Among all social media platforms, Twitter has acquired the most significant place in the decidedly political communication environments during the recent decade (Jungherr, 2016; Segesten \& Bossetta, 2017; Stier et al., 2018). As noted above, Twitter is also consumed and often amplified by journalists and, unlike its main competitor, Facebook, it has recently opened up access to historical data, which enables the kind of research presented here.

Using official EU webpages, we thus first identified all Twitter accounts of supranational executive institutions (i.e., excluding the intergovernmental and parliamentary branches of the EU). We include their main accounts (e.g., @EU_Commission), their individual subbranches (e.g., @EUHomeAffairs), and specialized EU agencies (e.g., @Frontex). In addition, we identified all accounts of individuals heading these institutions such as Presidents (e.g., @vonderleyen), Commissioners (e.g., @TimmermansEU), or Director-Generals (e.g., @lemaitre_eu). Including individuals is motivated by discussions about the personalization of supranational politics. "Giving a face" to institutions and personalized competition for EU office is a long-discussed strategy to channel the politicization of EU affairs (e.g., Hix, 1997). Even if the related Spitzenkandidaten process was never fully institutionalized, scholars observe a growing presidentialization of executive EU institutions (Hamřík, 2021; Kassim et al., 2017) and increased parliamentary scrutiny of leading EU officials (Wille, 2013). Moreover, the informal style on social media might be more akin to personalized communication. Thus, we also want to learn whether institutional and personal accounts differ in their comprehensibility and publicity.

Resorting to accounts active in May 2021 and officially verified to represent the respective person or organization by Twitter (the blue checkmark badge), we cover 70 institutional and 43 personal accounts. For each of these accounts, we then collect the full corpus of tweets they issued between joining Twitter (or the day of assuming executive EU office for personal accounts) and May 3, 2021 (one day before data collection) through the Twitter API 2.0 academic track. We arrive at a total population of 960,831 supranational social media messages. 
This offers a thus far unprecedented empirical perspective on supranational social media usage, which is hard to judge in absolute terms. We thus locate supranational communication patterns in three benchmark datasets. The first benchmark establishes "normal" behavior on the platform through a by-and-large random sample of tweets. We streamed in tweets from $26 \mathrm{EU}$ countries for a week with five-minute windows through Twitter Decahose API using "country b-box" as selection criterion. This generates a baseline of 83,823 "typical" tweets.

More importantly, the particular legitimacy and communication challenges of supranational actors emerge from the EU's nature as an unidentified political object, in the words of Jacques Delors (1985). On the one hand, its competencies approximate that of national executives. On the other, supranational executives are sometimes viewed as mere agents where member states guide and decide the exercise of political authority. Two benchmarks thus respectively address these different levels of governance.

To approximate social media communication of national executives, we target government ministers, ministries, executive offices, agencies, and individuals in charge of these institutions from the United Kingdom (UK). This country choice is initially pragmatic as English is the lingua franca of supranational tweets (see appendix A1 in the Supplementary File) and UK tweets can thus be directly benchmarked on our text-based indicators below. But the UK is also a substantially meaningful benchmark in the sense that, in terms of the social media penetration of its population, it is among the top 10 countries on the European continent, providing reason to assume that UK executives take this communication channel seriously. Collecting data analogously to the supranational EU actors, our UK sample ultimately yields 2,218,278 tweets from 72 institutional and 99 personal accounts.

Our third and final benchmark covers other regional organizations; that is, institutions in which a set of countries from a particular region pool or delegate certain political competences. The EU is arguably an extreme outlier in terms of pooling and delegation. It is less of an outlier, however, on the number of jointly decided policy areas. Thus, we identify a set of regional organizations, such as ASEAN, which have a roughly similar policy scope, picking those that are in the range of one standard deviation around the EU with regard to the number of policy areas coded in the MIA dataset (Hooghe et al., 2017). We then collected respective Twitter accounts from the list created and kindly shared by Ecker-Erhardt (2020). This results in 55 accounts having published 294,219 individual tweets.

In total, we compare the full population of 960,831 supranational tweets between 2009 and early 2021 to more than 2.6 million of such social media messages from random users and other executives on the national and regional level. The samples as well as the full list of EU, UK, and regional organizations' accounts are available for inspection in appendices A5-A8 in the Supplementary File.

The sheer volume of supranational social media messages already suggests that this communication channel is taken seriously. This holds when we consider the average number of tweets per supranational account and day over time, and compare these values to the UK and other regional organizations (Figure 1).

The number of supranational Twitter messages has increased nearly seven-fold from roughly one tweet every second day in 2009 to around 3.5 daily tweets during the last five years. The major growth period during 2010-2016 coincides with a growing overall prominence
Average daily number of tweets

by supranational EU accounts over time (smoothed)

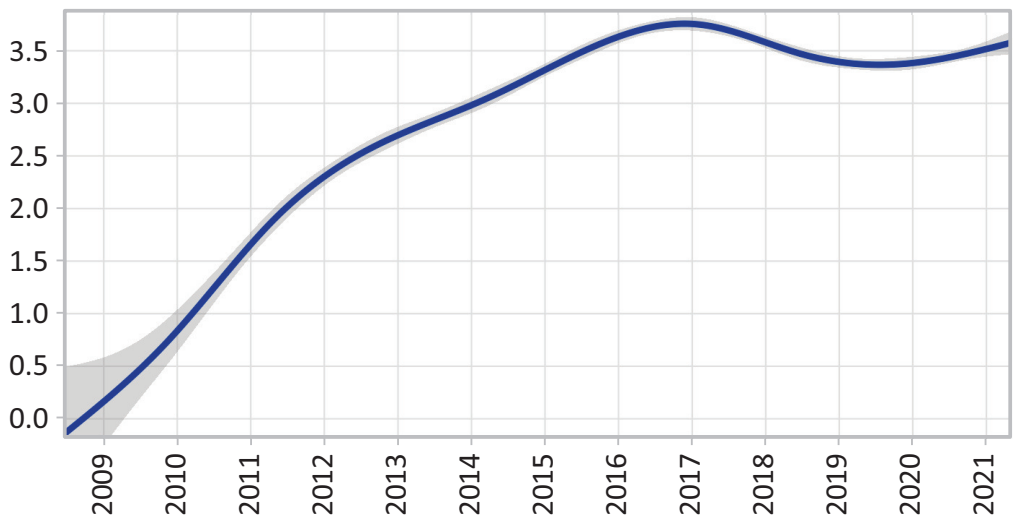

Figure 1. Tweet volume summaries.
Average daily number of tweets per account and actor type

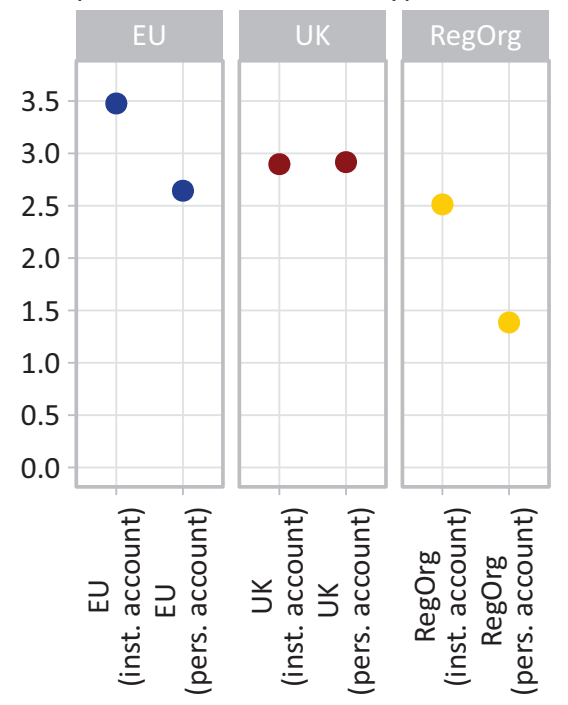


of Twitter. It also coincides with a strongly surging EU politicization amidst the Euro and Schengen crises, as well as with a notable reduction in the number of press releases from the European Commission (Rauh, 2021b). The growth we see may thus be explained by a mix of enhanced opportunity in this particular medium, increased strategic incentives from a politicized context, and a deliberate re-distribution of internal communication resources towards social media.

On the right-hand side of Figure 1, we see that this supranational tweet volume is driven largely by institutional accounts, also pointing to a planned approach to supranational social media presence. Across almost 13 years of supranational Twitter presence, institutional EU accounts emitted around 3.5 tweets per day, while supranational actors tweeting in personal capacity issued around one daily tweet less. The importance that supranational actors ascribe to this medium is also highlighted comparatively. The institutional accounts outperform executives both on the national and the regional level while individual executives are only marginally behind their peers on the national level.

There is variation, however. Among the most avid tweeters are the Commission's Directorate-General for Digital Policies (@DigitalEU, 13.7 daily tweets) and the official account of the whole EU Commission run by the spokespersons service (@EU_Commission, 10.4 daily tweets). On the lower end, we find the European Court of Justice (@EUCourtPress) with around one tweet every second day and the Euratom Supply Agency (@EuratomA) issuing a message only around every 10 days on average. Yet, this variation in supranational tweet volume (standard deviation: 2.58 daily tweets) is not really distinct from our UK sample (2.23 daily tweets), and is markedly lower than in our sample of regional organizations (4 daily tweets).

Therefore, in terms of sheer volume, EU supranational actors appear to be equally keen, if not keener than, as their peers to embark on public communication via Twitter. Volume alone, however, does not tell us whether the messages are actually geared to reach the wider European citizenry. Rather, we have identified comprehensibility and publicity as necessary conditions for effective public communication. We thus turn to more targeted indicators for both concepts in the two subsequent sections.

\section{The Comprehensibility of Supranational Twitter Messages}

\subsection{Text Comprehensibility}

For the question of whether supranational messages are comprehensible for the average citizen, the texts that supranational actors publish on Twitter provide key evidence. Scholars and pundits alike have repeatedly stressed that more communication does not help if it does not clarify-but rather obfuscates-political responsibilities (Fairclough, 2003; Fowler et al., 1979; Orwell, 1946). Especially detached and highly specialized institutions are accused to resort to a rather technocratic language, which requires high levels of formal education, uses specialized jargon, and gives priority to abstract developments rather than to political agency (Moretti \& Pestre, 2015; Rauh, 2021b; Thibault, 1991).

We operationalise these ideas along the validated text analysis tools provided by Benoit et al. (2019), and extract three variables from the English-language elements of each tweet (details in appendices A1 and A2 in the Supplementary File). First, the Flesch reading ease score measures syntactic complexity. This compound indicator of sentence and word length captures the required cognitive mobilization needed to grasp the textual content of a message (often mapped to formal education levels). Second, we measure the familiarity of the words in a tweet by their average frequency in the overall Google Books corpus as the broadest available representation of the general English language. Words that are more common are better known to and thus more readily comprehensible by a broad audience. Third, we use the verb-to-noun ratio to capture whether tweets help to make choices and processes transparent. Linguists stress that texts express political agency better when they resort to a verbal as opposed to a nominal style (Biber et al., 1998, p. 65). Using many nouns and nominalizations prioritizes abstract objects and processes over action. A higher share of verbs, in contrast, clarifies who did what, and provides more information on the temporal order of events and processes. Figure 2 presents the benchmarks for these three linguistic indicators of comprehensibility.

Compared to other regional organizations, supranational EU tweets send less complex messages with more familiar vocabulary. But in this comparison, they perform worse in clarifying agency through a more verbal style. More importantly, all three indicators suggest that the text of supranational social media messages is significantly harder to comprehend for the average citizen when compared to random Twitter messages or especially to the tweets of national institutions and executives. This clearly reaffirms a rather technocratic language of supranational communication that has been found in press releases as well (Rauh, 2021b).

But notable variation within the supranational population exists. Based on standardized averages of the three indicators, the messages by current Commission President Von der Leyen, Commissioners Timmermans and Vestager, and Matthew Baldwin (European Coordinator for Road Safety) are easiest to understand. The least accessible messageson average-are sent by the European Maritime Safety Agency, by the Commission Director-General for Competition Policy (ironically headed by the clearly communicating Margrethe Vestager), Justice Commissioner Reynders, and the European Defence Agency. Averaged across indicators, supranational tweets from personal 


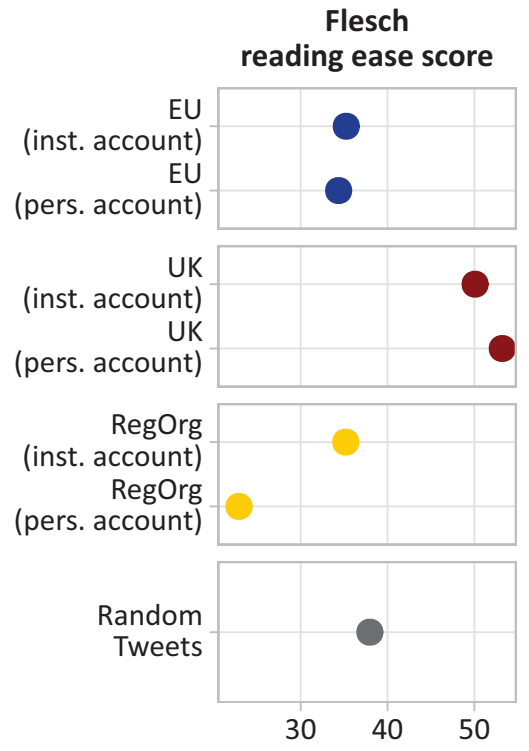

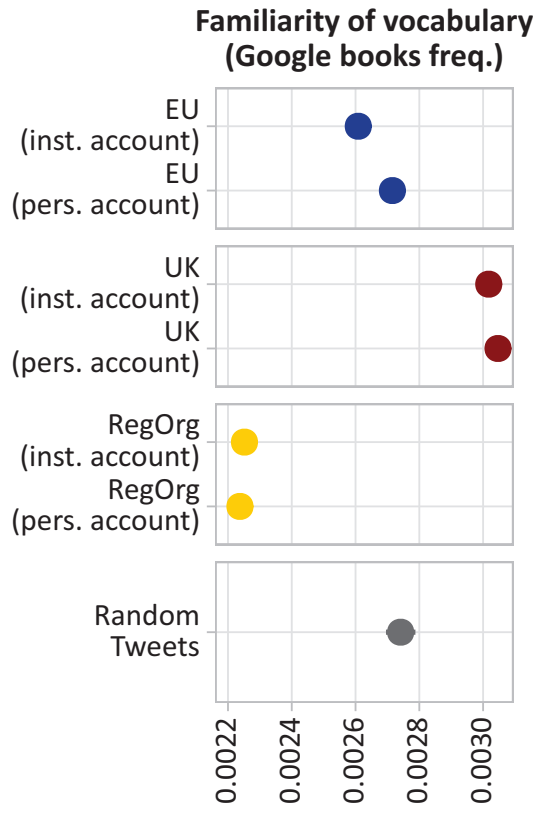

Only original tweets (excluding re-tweets and quotes) with English-language content.

Figure 2. Ease of read measures of tweets.

accounts tend to be easier to comprehend than tweets from institutional accounts.

\subsection{Media Content}

Beyond text, social media-Twitter in particular-offer multimedia features designed to attract attention and generate engagement. Symbols, pictures, or audiovisuals transmit large amounts of non-textual information, thereby aiding message comprehension (Tang \& Hew, 2018). We assess whether and to what extent supranational actors use this additional communication potential by retrieving embedded pictures, videos, and external links from the URL entities field in the Twitter API, and by collecting emojis and other special symbols from the tweet text. Figure 3 benchmarks the resulting data.

The top left panel of Figure 3 shows that more than $40 \%$ of all supranational tweets include at least one embedded picture. This clearly exceeds picture usage in the tweets by domestic political actors as well as by institutional accounts of other regional organizations. Videos also appear frequently in supranational tweets, at least in relative terms. Institutional supranational accounts feature a video in around $6 \%$ of all messages, which is only surpassed by the $8 \%$ of messages from national executive institutions in the UK.

Twitter is notorious for popularizing special characters and especially emoticons in public communication. The lower left panel of Figure 3 indicates that supranational EU tweeters champion such special symbols as well and much more than their executive peers. Additional analyses show that the by far most used symbol is the EU flag, appearing more than 50,000 times and thus in more than $5 \%$ of all supranational tweets. Flags of different individual countries appear in a combined total of about $7 \%$ of tweets. Beyond that, supranational actors like to use various pointing hand and arrow symbols, a pictogram of the globe, and various versions of checkmark symbols.

Finally, messages can be enriched by links to external online content (often provided as a media thumbnail in tweets) which facilitates further information-seeking for message recipients. On this feature supranational tweets are on par with or even exceed the shares of tweets with external links observed for domestic or regional executives. About $60 \%$ to $80 \%$ of all supranational messages refer to an external online source. Where these links lead citizens to cannot be fully ascertained as around $41 \%$ use URL shortening services. Yet, in the remainder, we see that supranational actors primarily refer to EU websites within the europa.eu domain (35\% of all external URLS), pointing message recipients especially to information from the European Commission's servers. A sizeable share of around $5 \%$ of external links point to other social media platforms, notably Facebook, Linkedln, and Instagram. Supranational actors also use services that automatically post content across different social media accounts (e.g., the dlvr.it domain accounts for around 3\% of all external links).

All in all, supranational actors try to aid message comprehension by exploiting the multimedia features that Twitter offers, partially more so than their peers on the national or regional level.

\section{Publicity of Supranational Messages}

As argued above, putting a supranational message on the ether is hardly enough. To affect wider legitimacy 

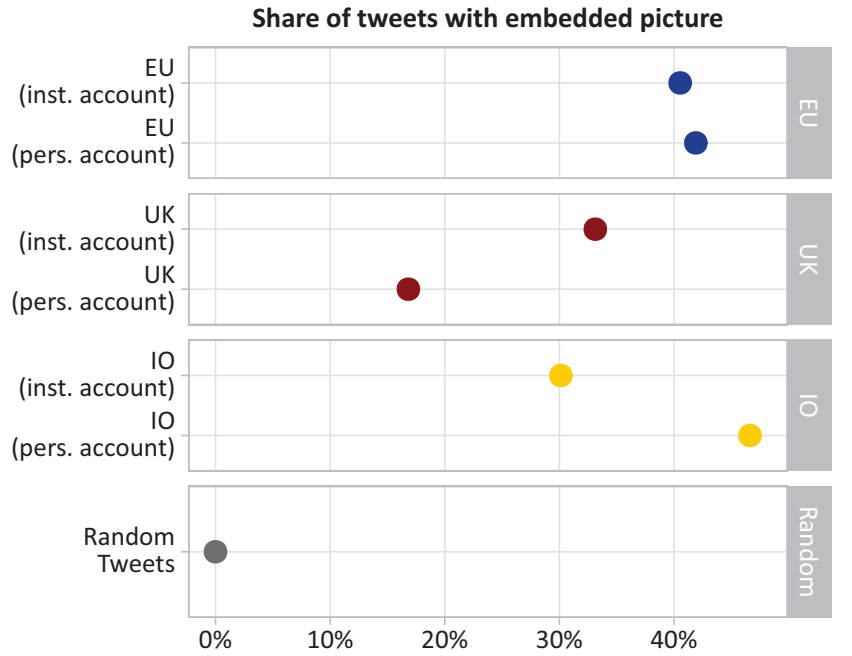

Emojis / special symbols per tweet
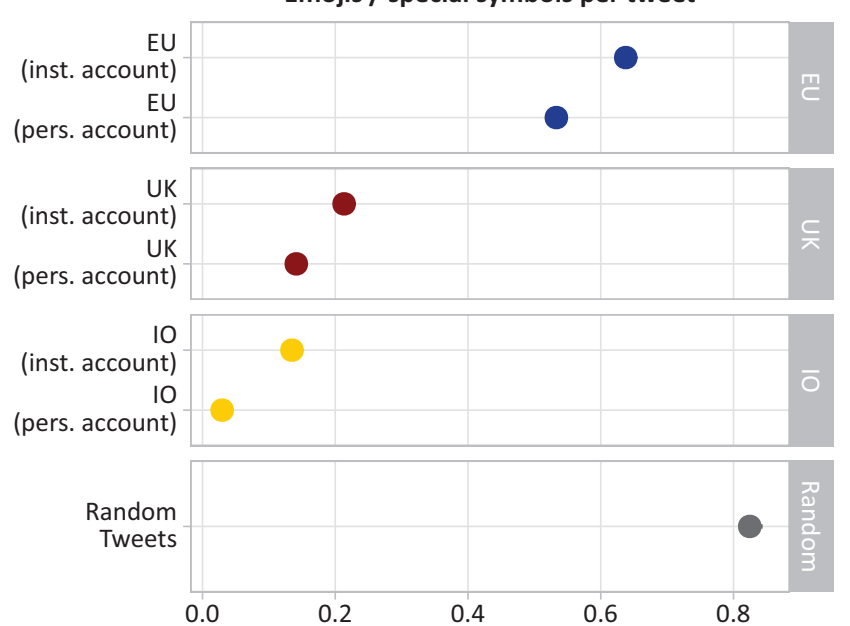

Figure 3. Non-textual element use in tweets.

beliefs, supranational communication needs to engage citizens to generate publicity. Our observational setting can unfortunately not ascertain who actually receives supranational tweets and what is triggered on part of these recipients. But the Twitter data allow-to some extent-analyzing at least the on-platform engagement of users.

An initial publicity indicator is the number of users who subscribe to or "follow" supranational accounts. As the Twitter APIs unfortunately do not offer respective historical data, we developed and share scripts extracting this information whenever an archive.org snapshot of the individual profile is available (see Appendix A3 in the Supplementary File). This shows that the growing volume of supranational tweets was followed by partially also dramatically increasing numbers of subscribers of supranational accounts. Yet, these follower counts are strongly right skewed, and this bias to few selected supranational accounts intensified over time. The by far most prominent account is @EU_Commission with $1,491,171$ followers as of May 4,2021 , followed by the
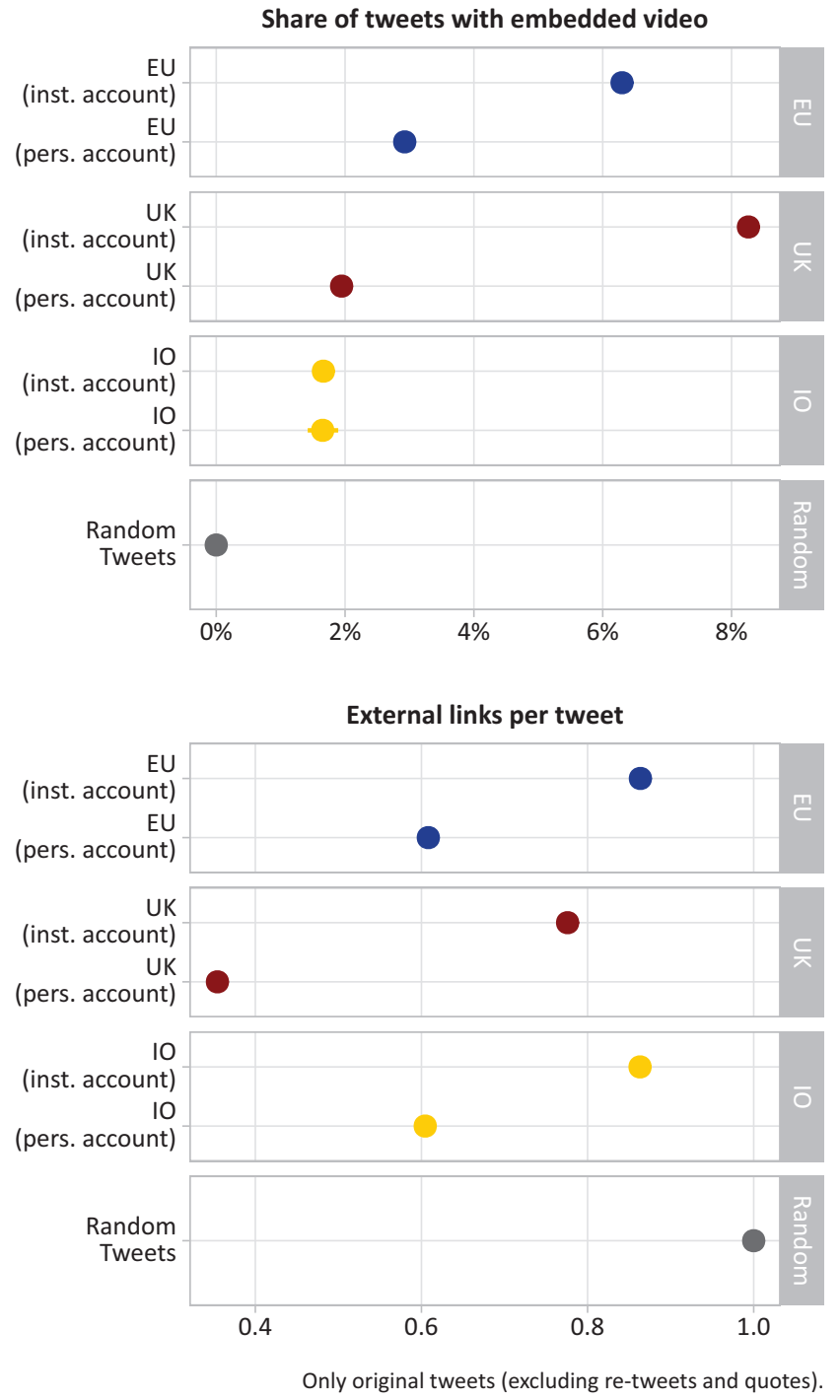

institutional accounts of the European Council President $(1,194,648$ followers) and the European Central Bank $(627,385)$. The most prominent personal accounts are Commission president Von der Leyen $(587,814$ followers), Competition Commissioner Vestager $(295,650)$, and the High Representative for Foreign Affairs and Security Policy, Josep Borell $(202,519)$. Personal accounts have on average 13,000 followers less than institutional accounts, but this difference is not statistically significant, indicating sizeable variation within both groups. At the lower end of the distribution, we find several Commission Directors-General as well as the Euratom Supply Agency with only 78 followers.

To study the average publicity of individual supranational messages, we analyze the on-platform engagement features Twitter offers. Users can like messages, may amplify or contextualize them by retweets or quotes, or can reply publicly. We collect the counts of these engagements in response to each original tweet. This raw data can be misleading as the engagement counts are constrained by the number of users that 
have seen a supranational message in the first place. Since the Twitter APIs unfortunately does not offer this number of "impressions," we normalize engagement counts against the interpolated number of followers at the time an account has published the respective tweet. Figure 4 plots these engagement ratios against our equally treated benchmark samples.

These data provide three main insights. First, supranational messages receive as much Twitter user engagement as messages from executive actors and institutions at the national and regional levels. Supranational messages are, in fact, slightly more frequently liked and retweeted than those from national institutions and actors in the UK. Only UK actors tweeting in personal capacity received a markedly higher share of quotes and replies on their messages. Second, across all samples, Twitter users tend to engage more strongly with personal accounts than with institutional ones. Personalization of political messaging seems to matter on this social medium, and this holds for supranational EU actors as well. Third, direct engagement with executive tweets is not particularly high in absolute terms. On average, the number of direct engagements with supranational tweets by either liking, retweeting, quoting, or replying does not exceed a share of $0.14 \%$ of the number of users following the respective account.

There are a few extreme outliers, however. For example, 18 tweets from our supranational sample receive
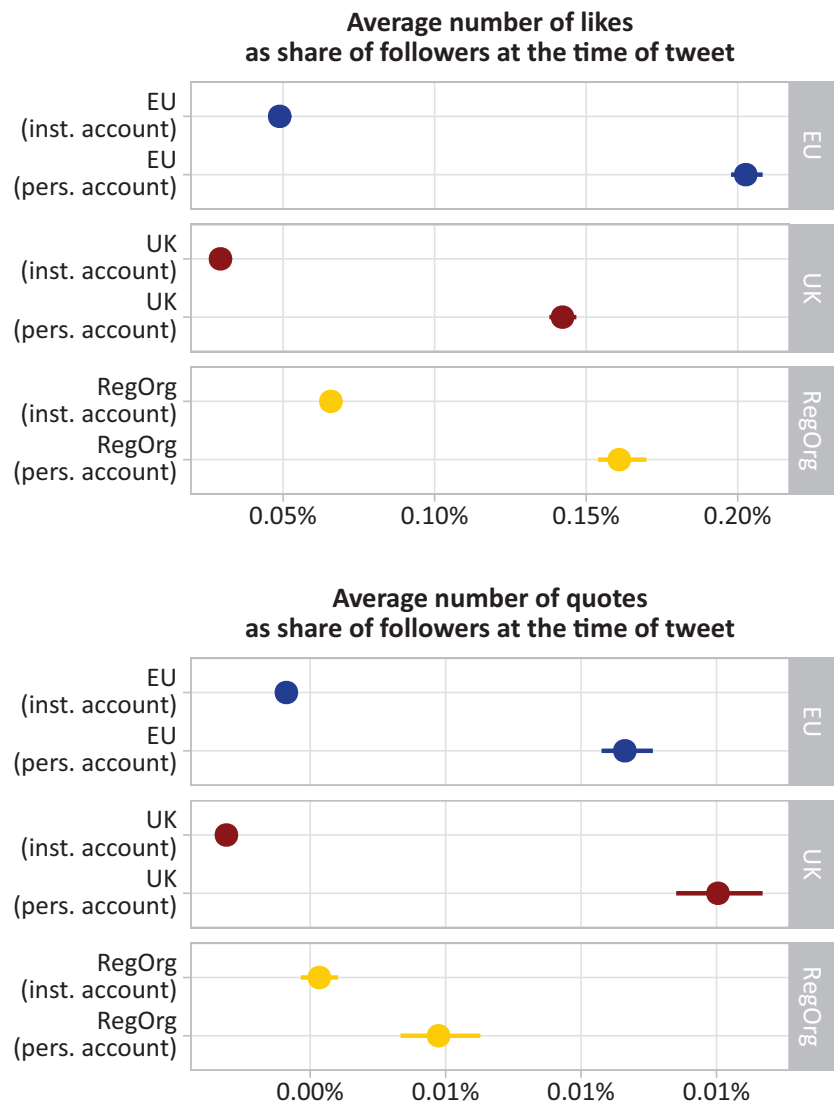

Figure 4. Engagement rates on Twitter. an engagement rate that exceeds $30 \%$ of the followers at the time the message was published. Table 1 provides six illustrative examples for such supranational tweets with extraordinary publicity on Twitter. We cannot readily generalize from so few outlying examples, but we note that the most engaging tweets in our sample invoke highly politicized EU issues. Examples are Commissioner Dalli's stance on LGBTI rights in Poland, the Frontex tweet including surveillance footage from the Mediterranean Sea (leading to a heated Twitter debate about whether priority should be given to sea rescue or the fight against human trafficking), the European Court of Justice's announcement that the UK may unilaterally revoke its withdrawal request, and the farewell note from the European Medicines Agency when finally leaving London due to Brexit.

These outliers also suggest that comprehensibility and publicity may be partially related. We see, for example, clear and concise language, numerous emojis, and embedded media links. How much these characteristics affect user engagement is hard to model exactly, as the proceedings of the Twitter algorithms are not known and tweet virality seems to follow partially endogenous dynamics and punctuated patterns. However, a solely exploratory multivariate perspective (appendix A4 in the Supplementary File) provides additional initial hints. Higher readability and a more verbal style of a tweet is associated with modestly higher user
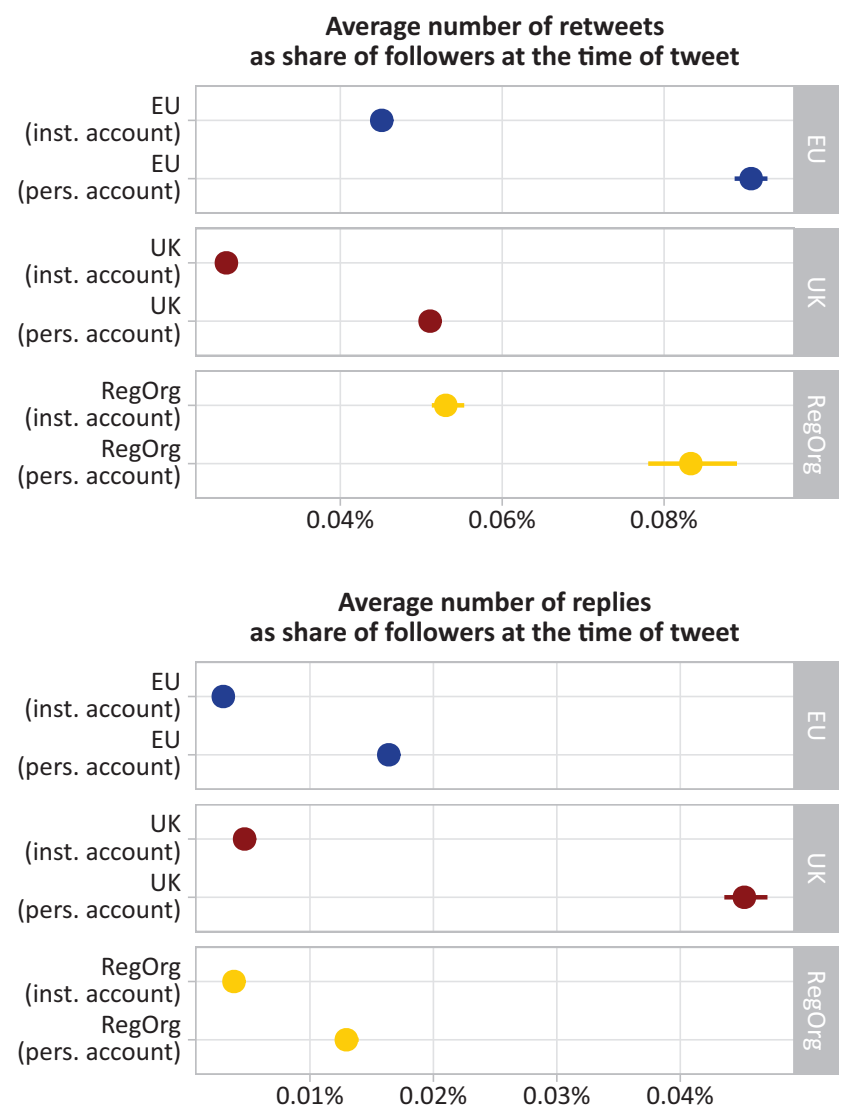
Table 1. Supranational tweet examples with extraordinary engagement rates.

\begin{tabular}{|c|c|c|c|c|}
\hline Tweet & Account & Date & Followers & $\begin{array}{c}\text { All direct } \\
\text { engagements }\end{array}$ \\
\hline $\begin{array}{l}\text { Meet Mismo a customs sniffer dog, who will tell } \\
\text { you all about his job. \#50CU \#DogsWithJobs More } \\
\text { info about the 50th anniversary of the EU } \\
\text { \#CustomsUnion: https://t.co/tD9clkog5q } \\
\text { https://t.co/5MXpNH3Fqy }\end{array}$ & @EU_Taxud & 2018-06-15 & 11,197 & 9,916 \\
\hline $\begin{array}{l}\text { EU values and fundamental rights must be respected } \\
\text { by Member States and state authorities. This is why } \\
6 \text { town twinning applications invilving Polish } \\
\text { authorities that adopted 'LGBTI free zones' or 'family } \\
\text { rights' resolutions were rejected. \#LGBTI } \\
\text { \#UnionOfEquality }\end{array}$ & @helenadalli & $2020-07-28$ & 9,756 & 8,036 \\
\hline $\begin{array}{l}\text { look at THIS !! The WHOLE core centre of brussels to } \\
\text { go to } 20 \mathrm{kph} \text { for the summer from } 1 \text { May with } \\
\text { priority to giving space to } \\
\text { the challenges of \#CoronaVirus to rethink and } \\
\text { transform mobility...right here in Brussels.... } \\
\text { https://t.co/RgmJNBgx89 }\end{array}$ & @BaldwinMatthew_ & $2020-04-20$ & 6,102 & 4,314 \\
\hline $\begin{array}{l}\text { Wait, wait. Why is that fishing trawler towing an } \\
\text { empty wooden boat at high seas??? } \\
\text { https://t.co/psy } 2 z 6 z 9 W p\end{array}$ & @Frontex & $2019-06-22$ & 23,214 & 11,861 \\
\hline $\begin{array}{l}\text { Today, EMA staff lowered the } 28 \text { EU flags and } \\
\text { symbolically said goodbye to their London offices. } \\
\text { Guido Rasi expressed his thanks to the UK for its } \\
\text { contribution to the work of the Agency and for } \\
\text { having been a gracious host of EMA since } 1995 \text {. } \\
\text { https://t.co/KpsBvaXt42 }\end{array}$ & @EMA_News & 2019-01-25 & 39,251 & 18,853 \\
\hline $\begin{array}{l}\text { \#ECJ: UK is free to unilaterally revoke the } \\
\text { notification of its intention to withdraw from the } \\
\text { EU-Case C-621/18 Wightman \#Brexit } \\
\text { https://t.co/KUOI2eQ48C }\end{array}$ & @EUCourtPress & $2018-12-10$ & 45,522 & 18,736 \\
\hline
\end{tabular}

engagement ratios. Visual information-embedded pictures and emojis-show an even stronger association with on-platform user engagement. Notably, even when controlling for such message characteristics, the advantage of personal accounts in triggering user engagement appears to be even more pronounced. Clearly, the relationships between message comprehensibility and user engagement warrant further research (cf. Firouzjaei \& Özdemir, 2020).

\section{Conclusions}

In the face of public politicization, popular legitimacy challenges, and notable communication obstacles, social media hold many promises as an additional channel through which the otherwise detached executive supranational actors of the EU can reach out to the citizenry. Thus far, however, an aggregate picture on whether and how these actors exploit the potential of social media has been lacking. We thus provide a bird's eye perspective analyzing and benchmarking the full population of the almost one million messages that 113 supranational Twitter accounts emitted in the 2009-2021 period.

Our encompassing description shows that the volume of supranational social media communication has grown markedly since 2010, having reached or even exceeding the number of posts that national executives or regional organizations with comparable policy scopes publish. Several of the observed patterns suggest a growing professionalization of supranational social media usage. Supranational actors make extensive use of Twitter's multimedia features, engage in cross-posting of social media content, and try to garner attention to their own online resources outside of Twitter. Supranational EU actors are in no way inferior but often better than domestic and international executives on Twitter in this regard. This communicative investment seems to pay off in terms of publicity; at least on the platform itself. 
The number of Twitter users subscribing to supranational EU accounts has been growing on average, and in dramatic ways for some. Direct user engagement with supranational messages on the platform is not particularly high in absolute terms, but it by and large corresponds to the engagement rates one can observe for executive messages from national and other regional executives.

Yet, our encompassing description also contains warning signs regarding basic necessary conditions for effective public communication of supranational affairs. Message comprehensibility for the average citizen is hampered by a comparatively high syntactical complexity, unfamiliar vocabulary, and a rather nominal style that may obfuscate political agency in the textual content that supranational actors post on Twitter. This corresponds to a rather technocratic style of communication that has been found in other supranational communication channels. Regarding publicity, we must note that the follower numbers and the engagement rates are hardly equally distributed across supranational communicators. They rather concentrate on a few selected institutional and high-profile individual accounts as well as on a small set of messages in the overall stream of communication. While social media may help supranational actors to circumvent traditional media selection logics, the punctuated publicity patterns we see suggest that also this environment is highly selective in amplifying certain actors and messages.

In sum, our bird's eye view indicates that social media communication is taken very seriously by supranational executives but it still reproduces some of the flaws present in more traditional media as well. Of course, these aggregate patterns can only be a starting point for understanding the nexus of public communication, social media platforms, and popular legitimacy. Whether and how the communication we describe affects the precarious societal legitimacy of supranational decision making requires further analysis. For scholars willing to dig deeper into this type of data, however, the patterns we show provide four points of guidance. First, the sobering findings on textual understandability highlight the need to dissect supranational messages further in terms of the claims that supranational actors make, including their relation to actual political activity. Whether these public messages are mere propaganda or genuine, transparent political accountability reporting would help us understand to what extent public communication contributes to or possibly undermines the popular legitimacy of supranational actors. Second, our qualitative examples for the most engaging tweets highlight variation across externally politicized topics and suggest that topical contents of messages may provide valuable hints on the publicity that supranational messages generate. Third, our findings highlight that especially visual content is part and parcel of supranational public communication on social media, requiring additional forms of content analysis. Fourth and finally, especially the on average clearer communication and higher engagement rates that accounts of individual supranational actors generate highlight that differences between institutionalized and personalized communication on EU affairs can be studied on social media in particular.

Finally, we would like to draw attention to notable pragmatic challenges pertaining to the study of citizen engagement with European politics on social media that we encountered. The first of these is the sheer data volume and the nested structure and variation that comes with it. On the one hand, access to such a rich amount of data, especially from comparatively transparent platforms such as Twitter, allows researchers to study very encompassing populations of messages and communicators, leading to less biased aggregate pictures. On the other hand, managing such large volumes of data entails major logistical problems with regard to storing, sharing, and analyzing the data-especially in a collaborative project. While collaborative coding is tremendously facilitated by services such as our preferred GitHub, such free-of-charge services quickly reach their limits with the amount of data we had to wrangle for the analyses here. With some creativity, these problems can be solved; but for reproducible, collaborative work, political scientists need better infrastructure. The same holds for processing power: With our means, the analyses presented here partially implied waiting for several hours to reshape the data or to summarize descriptive information from it. We also faced a steep learning curve with regard to formulating calls to the Twitter API and handling the comparatively complex and nested data structure it returns. With a view to the large amounts of visual information in the data we present, such technical challenges are likely to increase in the future. Finally, we also should note that, despite the unprecedented access to Twitter data, some notable and substantially important gaps persist especially with a view to study citizen engagement: In our case, we could only extract historical data on follower counts from an external and incomplete source while we were also lacking the number of "impressions" per tweet. Without this information, for example, it is hard to see in how far the on-platform engagement we observe is driven by the messages and their authors or by the algorithms that Twitter uses to show them to specific users on the platform. Yet and still, we hope that our bird's eye view indicates that it is worthwhile to overcome such challenges in future research.

\section{Acknowledgments}

This manuscript has benefitted from a discussion in the WZB global governance colloquium, critical and very constructive feedback from two anonymous reviewers, as well as very useful comments from the editors of this thematic issue. We are very grateful for these inputs.

\section{Conflict of Interests}

The authors declare no conflict of interests. 


\section{Supplementary Material}

Supplementary material for this article is available online in the format provided by the authors (unedited).

\section{References}

Altides, C. (2009). Making EU politics public: How the EU institutions develop public communication. Nomos.

Barisione, M., \& Michailidou, A. (Eds.). (2017). Social media and European politics: Rethinking power and legitimacy in the digital era. Palgrave Macmillan.

Benoit, K., Munger, K., \& Spirling, A. (2019). Measuring and explaining political sophistication through textual complexity. American Journal of Political Science, 63(2), 491-508.

Biber, D., Conrad, S., \& Reppen, R. (1998). Corpus linguistics: Investigating language structure and use. Cambridge University Press.

Biegoń, D. (2013). Specifying the arena of possibilities: Post-structuralist narrative analysis and the European Commission's legitimation strategies. JCMS: Journal of Common Market Studies, 51(2), 194-211.

Bijsmans, P., \& Altides, C. (2007). "Bridging the gap" between EU politics and citizens? The European Commission, national media and EU affairs in the public sphere. Journal of European Integration, 29(3), 323-340.

Bischof, D., \& Senninger, R. (2018). Simple politics for the people? Complexity in campaign messages and political knowledge. European Journal of Political Research, 57(2), 473-495.

Boomgaarden, H., de Vreese, C., Schuck, A., Azrout, R., Elenbaas, M., Vanspanje, J., \& Vliegenthart, R. (2013). Across time and space: Explaining variation in news coverage of the European Union. European Journal of Political Research, 52(5), 608-629.

Bossetta, M., Dutceac Segesten, A., \& Trenz, H.-J. (2017). Engaging with European politics through Twitter and Facebook: Participation beyond the national? In $\mathrm{M}$. Barisione \& A. Michailidou (Eds.), Social media and European politics: Rethinking power and legitimacy in the digital era (pp. 53-76). Palgrave Macmillan.

Bressanelli, E., Koop, C., \& Reh, C. (2020). EU actors under pressure: Politicisation and depoliticisation as strategic responses. Journal of European Public Policy, 27(3), 329-341.

Brüggemann, M. (2010). Information policy and the public sphere. Javnost-The Public, 17(1), 5-21.

Cage, J., Herve, N., \& Mazoyer, B. (2020). Social media and newsroom production decisions. Social Science Research Network. https://doi.org/10.2139/ ssrn.3663899

De Vreese, C. (2001). "Europe" in the news: A crossnational comparative study of the news coverage of key EU events. European Union Politics, 2(3), 283-307.

De Vreese, C., Banducci, S., Semetko, H., \& Boomgaar- den, H. (2006). The news coverage of the 2004 European Parliamentary election campaign in 25 countries. European Union Politics, 7(4), 477-504.

de Wilde, P., \& Trenz, H.-J. (2012). Denouncing European integration: Euroscepticism as polity contestation. European Journal of Social Theory, 15(4), 537554.

de Wilde, P., \& Zürn, M. (2012). Can the politicization of European integration be reversed? JCMS: Journal of Common Market Studies, 50(1), 137-153.

Delors, J. (1985). Speech by Jacques Delors (Luxembourg, 9 September 1985) [Speech transcript]. CVCE. https://www.cvce.eu/content/publication/2001/ 10/19/423d6913-b4e2-4395-9157-fe70b3ca8521/ publishable_en.pdf

Ecker-Ehrhardt, M. (2018). Self-legitimation in the face of politicization: Why international organizations centralized public communication. The Review of International Organizations, 13(4), 519-546.

Ecker-Ehrhardt, M. (2020). IO public communication going digital? Understanding social media adoption and use in times of politicization. In C. Bjola \& R. Zaiotti (Eds.), Digital diplomacy and international organisations: Autonomy, legitimacy and contestation (pp. 2-31). Routledge.

European Parliament Directorate General for Parliamentary Research Services. (2021). The Twitter activity of members of the European Council: A content analysis of EU leaders' use of Twitter in 2019-20. European Parliament. https://data.europa.eu/doi/ 10.2861/17201

Fairclough, N. (2003). Analysing discourse: Textual analysis for social research. Psychology Press.

Fazekas, Z., Popa, S. A., Schmitt, H., Barberá, P., \& Theocharis, Y. (2021). Elite-public interaction on Twitter: EU issue expansion in the campaign. European Journal of Political Research, 60(2), 376-396.

Firouzjaei, H. A., \& Özdemir, S. (2020). Effect of readability of political tweets on positive user engagement. In 2020 IEEE/ACM International Conference on Advances in Social Networks Analysis and Mining (ASONAM) (pp. 884-891). https://web.ntpu.edu.tw/ myday/doc/ASONAM2020/ASONAM2020_ Proceedings/pdf/papers/137_074_884.pdf

Fowler, R., Hodge, B., Trew, T., \& Kress, G. (1979). Language and control. Routledge.

Gerhards, J., Offerhaus, A., \& Roose, J. (2009). Wer ist verantwortlich? Die Europäische Union, ihre Nationalstaaten und die massenmediale Attribution von Verantwortung für Erfolge und Misserfolge. [Who is responsible? The European Union, its nation states and the mass media attribution of responsibility for successes and failures]. In F. Marcinkowski F. \& B. Pfetsch (Eds.), Politik in der Mediendemokratie [Politics in the media democracy] (pp. 529-558). VS Verlag für Sozialwissenschaften. https://doi.org/ 10.1007/978-3-531-91728-3_22

Hamř́k, L. (2021). Is there any "price" for making individ- 
ual EU politicians more important? The personalization of politics in the European Commission. Journal of European Integration, 43(4), 403-420.

Harteveld, E., Schaper, J., Lange, S. L. D., \& Brug, W. V. D. (2018). Blaming Brussels? The impact of (news about) the refugee crisis on attitudes towards the EU and national politics. JCMS: Journal of Common Market Studies, 56(1), 157-177.

Hartlapp, M., Metz, J., \& Rauh, C. (2014). Which policy for Europe? Power and conflict inside the European Commission. Oxford University Press.

Haßler, J., Magin, M., Russmann, U., \& Fenoll, V. (Eds.). (2021). Campaigning on Facebook in the 2019 European Parliament election: Informing, interacting with, and mobilising voters. Palgrave Macmillan. https://doi.org/10.1007/978-3-030-73851-8

Heinkelmann-Wild, T., \& Zangl, B. (2020). Multilevel blame games: Blame-shifting in the European Union. Governance, 33(4), 953-969.

Hix, S. (1997). Executive selection in the European Union: Does the Commission president investiture procedure reduce the democratic deficit? European Integration online Papers (EloP), 1(21). http://eiop.or.at/ eiop/texte/1997-021a.htm

Hobolt, S. B., \& Tilley, J. (2014). Blaming Europe? Responsibility without accountability in the European Union. Oxford University Press. https://doi.org/ 10.1093/acprof:oso/9780199665686.001.0001

Hooghe, L., \& Marks, G. (2009). A postfunctionalist theory of European integration: From permissive consensus to constraining dissensus. British Journal of Political Science, 39(1), 1-23.

Hooghe, L., Marks, G., Lenz, T., Bezuijen, J., Ceka, B., \& Derdeyan, S. (2017). Measuring international authority: A postfunctionalist theory of governance (Volume III). Oxford University Press.

Hüller, T. (2007). Assessing EU strategies for publicity. Journal of European Public Policy, 14(4), 563-581.

Jungherr, A. (2016). Twitter use in election campaigns: A systematic literature review. Journal of Information Technology \& Politics, 13(1), 72-91.

Kassim, H., Connolly, S., Dehousse, R., Rozenberg, O., \& Bendjaballah, S. (2017). Managing the house: The Presidency, agenda control and policy activism in the European Commission. Journal of European Public Policy, 24(5), 653-674.

Koopmans, R., \& Statham, P. (2010). The making of a European public sphere. Cambridge University Press.

Krzyżanowski, M. (2020). Digital diplomacy or political communication? Exploring social media in the EU institutions from a critical discourse perspective. In C. Bjola \& R. Zaiotti (Eds.), Digital diplomacy and international organisations: Autonomy, legitimacy and contestation (pp. 52-73). Routledge.

Meyer, C. (1999). Political legitimacy and the invisibility of politics: Exploring the European Union's communication deficit. JCMS: Journal of Common Market Studies, 37(4), 617-639.
Moretti, F., \& Pestre, D. (2015). Bankspeak: The language of World Bank reports. The New Left Review, 92, 75-99.

Nulty, P., Theocharis, Y., Popa, S. A., Parnet, O., \& Benoit, K. (2016). Social media and political communication in the 2014 elections to the European Parliament. Electoral Studies, 44, 429-444.

Orwell, G. (1946). Politics and the English language. Horizon, 13(76), 252-265.

Oschatz, C., Stier, S., \& Maier, J. (2021). Twitter in the news: An analysis of embedded tweets in political news coverage. Digital Journalism. Advance online publication. https://doi.org/10.1080/21670811. 2021.1912624

Rauh, C. (2021a). Between neo-functionalist optimism and post-functionalist pessimism: Integrating politicisation into integration theory. In N. Brack \& S. Gürkan (Eds.), Theorising the crises of the European Union (pp. 119-137). Routledge.

Rauh, C. (2021b). From the Berlaymont to the citizen? The language of European Commission press releases 1985-2020 [Paper presentation]. 2021 Annual Convention of the International Studies Association. https://www.researchgate.net/publication/ 350152854_From_the_Berlaymont_to_the_citizen_ The_language_of_European_Commission_press_ releases_1985-2020

Rauh, C. (2021c). Supranational emergency politics? What executives' public crisis communication may tell us. Journal of European Public Policy. Advance online publication. https://doi.org/10.1080/13501 763.2021.1916058

Rauh, C., Bes, B. J., \& Schoonvelde, M. (2020). Undermining, defusing or defending European integration? Assessing public communication of European executives in times of EU politicisation. European Journal of Political Research, 59(2), 397-423.

Risse, T. (2014). European public spheres: Politics is back. Cambridge University Press.

Rittberger, B., Schwarzenbeck, H., \& Zangl, B. (2017). Where does the buck stop? Explaining public responsibility attributions in complex international institutions. JCMS: Journal of Common Market Studies, 55(4), 909-924.

Schafer, C., Schlipphak, B., \& Treib, O. (2021). The ideal setting of the EU in the mind of European citizens. University of Muenster. https://reconnect-europe.eu/ wp-content/uploads/2021/04/D9.2.pdf

Schimmelfennig, F. (2020). Politicisation management in the European Union. Journal of European Public Policy, 27(3), 342-361.

Schlipphak, B., \& Treib, O. (2017). Playing the blame game on Brussels: The domestic political effects of EU interventions against democratic backsliding. Journal of European Public Policy, 24(3), 352-365.

Segesten, A. D., \& Bossetta, M. (2017). A typology of political participation online: How citizens used Twitter to mobilize during the 2015 British general elec- 
tions. Information, Communication \& Society, 20(11), 1625-1643.

Silva, T., Kartalis, Y., \& Lobo, M. C. (2021). Highlighting supranational institutions? An automated analysis of EU politicisation (2002-2017). West European Politics. Advance online publication. https://doi.org/ 10.1080/01402382.2021.1910778

Stier, S., Bleier, A., Lietz, H., \& Strohmaier, M. (2018). Election campaigning on social media: Politicians, audiences, and the mediation of political communication on Facebook and Twitter. Political Communication, 35(1), 50-74.

Tallberg, J., \& Zürn, M. (2019). The legitimacy and legitimation of international organizations: Introduction and framework. The Review of International Organizations, 14(4), 581-606.

Tang, Y., \& Hew, K. F. (2018). Emoticon, emoji, and sticker use in computer-mediated communications: Understanding its communicative function, impact, user behavior, and motive. In L. Deng, W. W. K. Ma, \& C. W. R. Fong (Eds.), New media for educational change (pp. 191-201). Springer.

Thibault, P. J. (1991). Grammar, technocracy, and the noun. In E. Ventola (Ed.), Functional and systemic linguistics: Approaches and uses (pp. 281-306). Walter de Gruyter.

Tolochko, P., Song, H., \& Boomgaarden, H. (2019). "That looks hard!": Effects of objective and perceived textual complexity on factual and structural political knowledge. Political Communication, 36(4), 609-628.

Traber, D., Schoonvelde, M., \& Schumacher, G. (2020). Errors have been made, others will be blamed: Issue engagement and blame shifting in prime minister speeches during the economic crisis in Europe. European Journal of Political Research, 59(1), 45-67.

Trenz, H. (2008). Understanding media impact on European integration: Enhancing or restricting the scope of legitimacy of the EU? Journal of European Integration, 30(2), 291-309.

Trenz, H.-J. (2004). Media coverage on European governance: Exploring the European public sphere in national quality newspapers. European Journal of Communication, 19(3), 291-319.

Umit, R. (2017). Strategic communication of EU affairs: An analysis of legislative behaviour on Twitter. Journal of Legislative Studies, 23(1), 93-124.

Wallace, J. (2018). Modelling contemporary gatekeeping. Digital Journalism, 6(3), 274-293.

Walter, S. (2017). Explaining the visibility of EU citizens: A multi-level analysis of European Union news. European Political Science Review, 9(2), 233-253.

Weber, M. (2013). Kapitel III. Typen der Herrschaft [Chapter III. Types of authority]. In K. Borchardt, E. Hanke, \& W. Schluchter (Eds.), Max Weber Gesamtausgabe I/23. Wirtschaft und Gesellschaft: Soziologie [Max Weber complete edition I/23. Economy and society: Sociology] (pp. 449-591). Mohr Siebeck.

Wille, A. (2013). The normalization of the European Commission: Politics and bureaucracy in the EU executive. Oxford University Press.

Zaiotti, R. (2020). The (UN)making of international organisations' digital reputation: The European Union, the "refugee crisis," and social media. In C. Bjola \& R. Zaiotti (Eds.), Digital diplomacy and international organisations: Autonomy, legitimacy and contestation (pp. 207-226). Routledge.

\section{About the Authors}

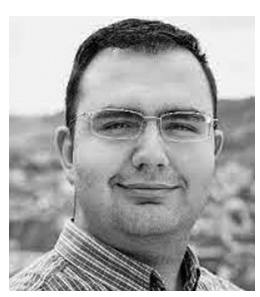

Sina Özdemir is a PhD candidate at the Department of Sociology and Political Science of the Norwegian University of Science and Technology (NTNU). His research interests cover EU studies, political psychology, political communication, international relations, and political sociology. Besides EU public communication, he is interested in political cleavage formation at different levels as well as social and psychological antecedents of such political phenomenon.

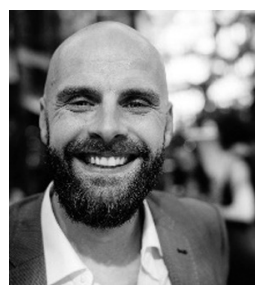

Christian Rauh, PhD, is a senior researcher at the Global Governance Unit of the WZB Berlin Social Science Center. He studies decision-making in and of the European Union with a particular interest in how it affects and is affected by controversial public debates. For more information, publications, or data please visit www.christian-rauh.eu 